\title{
Exhaled Carbon Monoxide Levels and Demographics of Waterpipe Smoking Young at Outdoor Areas of Waterpipe Smoking Cafes, in Ankara
}

\author{
Ankara'daki Nargile Kafelerde Dış Ortamda Nargile Içen Gençlerin Demografik \\ Verilerinin ve Ekshale Edilen Karbon Monoksit Düzeylerinin Değerlendirilmesi
}

\author{
(ㄱ) Illknur Bostancı 1, () Rukiye Ünsal Saç², (1) Dilek Kahvecioğlu33, (1) Serhat Emeksiz4, \\ i) Medine Ayşin Taşar²
}

'University of Health Sciences, Dr. Sami Ulus Women's and Children's Health and Research Teaching Hospital, Department of Pediatric Allergy and Asthma, Ankara, Turkey

2University of Health Sciences, Ankara Training and Research Hospital, Pediatric Clinic, Ankara, Turkey

${ }^{3}$ University of Health Sciences, Ankara Training and Research Hospital, Pediatric Clinic, Neonatal Intensive Care Unit , Ankara, Turkey ${ }^{4}$ Yildirim Beyazit University, Faculty of Medicine, Department of Pediatrics, Ankara, Turkey

\begin{abstract}
Aim: Waterpipe smokers are exposed to several toxicants, including carbon monoxide (CO), causing potential health effects. The aim of the study was to investigate demographic features and exhaled CO levels of waterpipe smoking (WPS) young.

Material and Method: The study was implemented at the outdoor areas (open air) of WPS cafes, in Ankara, in August. Demographic characteristics and exhaled CO levels of young were detected before and after one hour of WPS.

Results: In 59 participants, $79.7 \%(n=47)$ were males. Mean age was $21.8 \pm 3.7$ years and $62.7 \%$ were students. The most common reasons for WPS were socialization (79.7\%). Among waterpipe smokers, $47.4 \%(n=28)$ were also cigarette smokers. Among attendees, five (8.5\%) had asthma diagnosis, and nine (15.3\%) had one of their parents with asthma. Mean exhaled CO levels before and after WPS were $1.4 \pm 1.2 \mathrm{ppm}$ and $9.4 \pm 5.3 \mathrm{ppm}$ respectively $(p=0.001)$. Males and cigarette smokers had higher mean exhaled CO levels, before WPS ( $p=0.033$ and $p=0.001$, respectively). A significant correlation was detected between duration of WPS (years) and with exhaled CO levels before $(p=0.005, r=0.363)$ and after WPS $(p=0.039, r=0.270)$. In association with the rise in daily number of cigarettes, a rise in exhaled CO levels was also detected after WPS $(p=0.044, r=0.383)$.

Conclusion: In Ankara, nearly half of WPS young are also cigarette smokers, are mostly students or unemployed, and WPS is perceived as a social event. Males, cigarette smokers and longer years of WPS practice are associated with higher mean exhaled CO levels.Large cohort studies, especially targeting high-risk groups are needed in understanding how to curb WPS and take environmental and policy controls.
\end{abstract}

Keywords: Waterpipe smoking, exhaled carbon monoxide levels, young

\section{Öz}

Amaç: Nargile kullanıcıları, karbon monoksit (CO) dahil olmak üzere çeşitli toksik maddelere maruz kalarak birçok potansiyel sağlık sorunlarıyla karşı karşıya kalabilirler. Bu çalışmanın amacı, gençler arasında nargile kullanımının demografik özelliklerini ve ekshale edilen CO düzeyleri üzerine etkisin araştırmaktır.

Gereç ve Yöntem: Çalışma Ankara'da bulunan nargile kafelerin dış mekanlarında (açık hava) Ağustos ayında gerçekleștirildi. Gençlerin demografik özellikleri, nargile kullanımı öncesi ve kullanımdan bir saat sonra ekshale edilen CO düzeyleri ölçüldü.

Bulgular: 59 katılımcının \%79,7'si ( $n=47)$ erkekti. Yaş ortalaması 21,8 $\pm 3,7$ yıl ve \% 62,7'si öğrenciydi. Nargile kullanımının en yaygın nedeni sosyalleşmeyd $(\% 79,7)$. Nargile içenlerin \%47,4'ü $(n=28)$ aynı zamanda sigara kullanmaktaydı. Katılımcilardan $5^{\prime}$ inde $(\% 8,5)$ astım tanısı ve 9 'unun $(\% 15,3)$ da ailesinde astım öyküsü vardı. Nargile kullanımı öncesi ve sonrası ortalama ekshale edilen CO seviyeleri sırasıyla 1,4 $\pm 1,2 \mathrm{ppm}$ ve 9,4 $\pm 5,3 \mathrm{ppm}$ idi $(\mathrm{p}=0,001)$. Erkeklerde ve sigara içenlerde nargile kullanımı öncesinde ortalama ekshale edilen CO değerleri daha yüksekti (sırasıyla $p=0,033$ ve $p=0,001$ ). Nargile kullanım süresi (yıl) ile nargile kullanımı öncesi ( $p=0,005, r=0,363)$ ve sonrası $(p=0,039$, $r$ $=0,270$ ) ekshale edilen CO düzeyleri arasında pozitif bir korelasyon saptandı. Günlük sigara kullanım sayısı ile nargile kullanımı sonrası ekshale edilen CO düzeyleri arasında istatiksel olarak anlamlı bir ilişki saptandı ( $p=0,044, r=0,383)$.

Sonuç: Ankara'da nargile kullanan gençlerinin yaklaşık yarısı aynı zamanda sigara kullanmakta, çoğunluğu öğrenci veya işsiz ve nargile kullanımı sosyal bir olay olarak algılanmaktadır. Erkek cinsiyet, sigara içimi ve daha uzun yıllardır nargile kullanımı, daha yüksek ortalama ekshale CO düzeyleri ile ilişkilidir.

Nargile kullanımını engellemek için, özellikle yüksek riskli grupları hedefleyen alınacak çevre ve politika önlemleri için yol gösterici olacak büyük kohort çalışmalarına ihtiyaç vardır.

Anahtar Kelimeler: Nargile kullanımı, ekshale edilen karbon monoksit düzeyleri, gençler

Corresponding (IIletişim): Dilek Kahvecioğlu, Associate professor of Pediatrics, University of Health Sciences, Ankara Training and Research Hospital, Pediatric Clinic, Neonatal Intensive Care Unit, Ankara, TURKEY

E-mail (E-posta): dileksaracoglu@yahoo.com

Received (Geliş Tarihi): 03.01.2020 Accepted (Kabul Tarihi): 07.07.2020 


\section{INTRODUCTION}

Tobacco use is one of the most important reasons for preventable mortalities, causing approximately six million deaths per year. World Health Organization estimates that, unless urgent action is taken, the annual death toll would rise to more than eight million by $2030 .{ }^{[1]}$

A worldwide campaign is conducted against cigarette smoking, which is the most common form of tobacco used. However, there are other ways of tobacco use apart from cigarettes; one of them is waterpipe use. ${ }^{[2,3]}$ One WPS period lasts for 30-60 minutes and contains approximately over 100 inhalations. The composition and amount of tobacco used in waterpipe has no standardization, and can be mixed with other addiction substances. ${ }^{[2,3]}$ Waterpipe smoke contains many of the same toxicants as cigarette smoke. The nicotine amount in daily waterpipe users is at the same level as those smoking 10 cigarettes a day. ${ }^{[2,3]}$

The belief that WPS is less harmful compared to cigarette smoking, its being easily attainable, the cheap cost, the attractive pipe decorated with floral and other motifs, and aromatic taste of the tobacco used in WPS are held responsible for its spread as a global risk to public health. ${ }^{[2]}$ The recent trend is a social activity among adolescents that takes place at WPS cafes. ${ }^{[3,5,6]}$ These cafes are a facility of common used areas among young, provoking a significant increase in WPS. ${ }^{[7]}$

Though there is more need for epidemiologic investigations, it is known that WPS is related to important problems such as malignancies, cardiovascular system diseases, decreased vital capacity, nicotine addiction and the risk of spreading infectious diseases ${ }^{[4]}$ Carbon monoxide (CO) exposure was also reported to be intense with WPS4. Exhaled CO (eCO) levels in expired breath are a quantitative measurement to assess smoking habit of a person and correlates correctly with carboxyhemoglobin levels in blood. It was reported that exposure to waterpipe smoke is a cause of elevated eCO levels in smokers and passive smokers. ${ }^{[5]}$

The purpose of this study is to evaluate the perceptions and sociodemographic characteristics of WPS young in WPS smoking cafes, in Ankara. The other aim is to compare the increment of eCO in the breath of young, pre and post WPS.

\section{MATERIAL AND METHOD}

This was a cross-sectional study, which was conducted in 12 WPS cafes, that agreed to participate in the study. in Ankara, in August. Authors went to these cafes after finishing their work time, after $5 \mathrm{pm}$. The study was conducted between 18:00 and 22:00 hours. Informed consent was obtained from all the participants and the ethics committee of Ministry of Health, Ankara Education and Research Hospital approved the study. Ethical approval: (Reference Number: 0058.286). The equipments required for the study were a carboximeter, disposable mouthpieces and questionnaire forms. The carboximeter was made in England and brand name was Bedfont microsmokerlyzer.
Throughout the year, the lowest average concentrations of particulate matter was observed in august and warning threshold value did not exceed at any day of this month in Ankara. ${ }^{[8]}$

The study site was open areas of WPS cafes, in order to avoid influences of indoor pollution and passive smoking. Openair WPS cafes, not exposed to outdoor sources of pollution including vehicle pollution were chosen. Before beginning to WPS, the participant took a deep breath, held it for 15 seconds and blew out to the carboximeter. This eCO level before WPS was recorded. PreWPS measurements were performed before the first WPS smoked that day. Then, after the end of one hour WPS, eCO analyze was repeated.

Pre and post WPS eCO levels were recorded as parts per million (ppm) percentages. By interviewing with the participant face to face, a questionnaire was filled including the questions below:

-How many years and how frequently (day, week, or monthly) have you been WPS?

-How many hours do you spend time at WPS cafe?

-How long does one period of WPS last (hours)?

-How often do you visit WPS cafe?

-What is your reason to begin using WPS?

-How did you become an addictor of WPS?

-Do you or your parents have asthma diagnosed by a doctor?

-Are you also a cigarette smoker? If yes, what is the reason? For how many years have you been and how many cigarettes a day?

-Do your parents use tobacco?

-What is your occupation?

If a participant is a type of chronic drug user, or had used any drug or drunk soda containing drink before the pre WPS eCO measurement time on the same day, this was excluded from the study.

\section{Statistical Analysis}

The data were evaluated using Statistical Program for Social Sciences (SPSS Inc. Chicago, IL, USA) 16.0 statistical analysis package program. Chi-square test was used for qualitative variables in statistical comparisons. Normal distribution of quantitative variables was evaluated using KolmogorovSmirnow $Z$ (K-S) test. Student $t$ test was used in comparison of two independent groups, because the distributions were compatible with the normal distribution. Pre and post WPS, eCO levels were tested with paired samples t test.

Bivariate associations between continuous variables were assessed by Pearson's correlation test.

A $p$ value of $<0.05$ was considered statistically significant. 


\section{RESULTS}

Among 59 young, $79.7 \%(n=47)$ were males and $62.7 \%$ were students. Study group's mean age was 21.8 \pm 3.7 (min 15-max 32 ) years. Median years of WPS were 3 (min 1-max 10). Among the participations, $47.5 \%(n=28)$ were smoking waterpipe every day, and one period of WPS was median two hours (min 1-max 4). Demographic data of the waterpipe smokers are presented in Table 1.

Among attendees, five (8.5\%) had asthma diagnosis, and nine (15.3\%) had one of their parents with asthma (Table 1).

\begin{tabular}{lc}
$\begin{array}{l}\text { Table 1. Demographic characteristics of the WPS adolescents in WPS cafes } \\
(\mathrm{n}=59)\end{array}$ & $\mathbf{n}(\%)^{*}$ \\
\hline Variable & $21.8 \pm 3.7$ \\
\hline Age (years) (mean \pm SD) & \\
\hline Gender & $47(79.7)$ \\
$\quad$ Male & $12(20.3)$ \\
$\quad$ Female & \\
\hline Occupation & $37(62.7)$ \\
$\quad$ Student & $16(27.1)$ \\
Unemployed & $6(10.2)$ \\
$\quad$ Employed & $3(1-10)$ \\
\hline Years of WPS practice & \\
$\quad$ [median (average)] & $28(47.5)$ \\
\hline Frequency of water pipe smoking & $13(22.0)$ \\
$\quad$ Everyday & $18(30.5)$ \\
\hline Weekly & \\
$\quad$ Monthly & $2(1-4)$ \\
\hline Duration of one period of water pipe smoking (hours) & \\
$\quad$ [median (average)] & $2(1-5)$ \\
\hline Time spent at the cafe (hours) & $28(47.4)$ \\
[median (average)] & $21(35.6)$ \\
Cigarette smoker & $5(8.5)$ \\
Alcohol drinker & $9(15.3)$ \\
\hline Has asthma diagnosis & \\
Parents have asthma diagnosis & \\
\hline *: Column percent & \\
\hline
\end{tabular}

The most common reason stated for WPS was socialization (79.7\%). The effect and advice of the friends was the most important reason to get addicted to WPS (69.5\%) (Table 2).

\section{Table 2. Reasons stated for smoking and getting addicted to WPS}

\begin{tabular}{lc} 
Variable & $\mathbf{n}(\%)^{*}$ \\
\hline Reason for WPS & \\
Socialization/partying & $47(79.7)$ \\
Pleasant taste, sound or smell & $7(11.9)$ \\
Stress and tension relief or relaxation & $4(6.7)$ \\
To spend time and hang around & $1(1.7)$ \\
\hline How he/she got addicted to WPS & \\
The effect and advice of the friends & $41(69.5)$ \\
Curiosity & $15(25.4)$ \\
$\quad$ Emulation & $3(5.1)$ \\
\hline *: Column percent & \\
\hline
\end{tabular}

In the study group, that comprises entirely waterpipe smokers, $47.5 \%(n=28)$ were also cigarette smokers. Cigarette smokers were cigarette smoking for a mean of $5.3 \pm 4.2$ years (min 1-max 20) (Table 3). Mean age of cigarette smokers (20.8 \pm 3.5 years) were lower than the mean age of non-cigarette smokers $(22.9 \pm 3.7$ years) $(p=0.044)$; and the rate of males were higher than females $(p=0.023)$. The most frequent reason registered to begin cigarette smoking was curiosity (39.3\%).

\section{Table 3. Demographic characteristics of the cigarette smokers}

\begin{tabular}{lc} 
Variable & Value, $\mathbf{n}(\%)$ \\
\hline Age (years) (mean \pm SD) & $20.8 \pm 3.5(15-30)$ \\
\hline Gender & $26(92.9)$ \\
Male & $2(7.1)$ \\
$\quad$ Female & \\
\hline How he/she was had begun cigarette $(\mathrm{n}=28)$ & $11(39.3)$ \\
$\quad$ Curiosity & $9(32.2)$ \\
Peer pressure & $8(28.5)$ \\
Emulation & $5.3 \pm 4.2(1-20)$ \\
Years of cigarette practice (mean \pm SD) & $15.6 \pm 8.0(3-40)$ \\
Daily number of cigarettes smoked $($ mean \pm SD) & $7(11.9)$ \\
Mother is a cigarette smoker & $16(27.1)$ \\
Father is a cigarette smoker &
\end{tabular}

Mean eCO levels pre and post one hour WPS were $1.5 \pm 1.3 \mathrm{ppm}$ (min 0.1-max 5.6) and 9.4 55.3 ppm ( $\min 3-\max 25)$, respectively $(p=0.001)$. Males had higher mean pre WPS eCO levels than females (1.6 $\pm 1.3 \mathrm{ppm}$ and $0.8 \pm 0.7 \mathrm{ppm}$, respectively) $(p=0.033)$. In addition, cigarette smokers had higher mean pre WPS eCO levels than non-cigarette smokers $(2.0 \pm 1.5 \mathrm{ppm}$ and $1.0 \pm 0.8$ ppm, respectively) $(p=0.001)$ (Table 4).

\begin{tabular}{|c|c|c|c|}
\hline & $\begin{array}{c}\text { Pre WPS } \\
\text { (ppm) }\end{array}$ & $\begin{array}{c}\text { Post WPS } \\
\text { (ppm) }\end{array}$ & $\mathbf{p}$ \\
\hline Total eCO levels (mean \pm SD) (n:59) & $1.5 \pm 1.3$ & $9.4 \pm 5.3$ & $p=0.001$ \\
\hline \multicolumn{4}{|l|}{ Gender (mean \pm SD) } \\
\hline Male (n:47) & $1.6 \pm 1.3$ & $9.9 \pm 5.3$ & $p=0.001$ \\
\hline Female (n:12) & $0.8 \pm 0.7$ & $7.4 \pm 4.8$ & \\
\hline \multicolumn{4}{|l|}{ Cigarette Smoker (mean \pm SD) } \\
\hline Yes (n:28) & $2.0 \pm 1.5$ & $9.1 \pm 4.7$ & $p=0.001$ \\
\hline No $(n: 31)$ & $1.0 \pm 0.8$ & $9.6 \pm 5.8$ & \\
\hline \multicolumn{4}{|c|}{ Frequency of water pipe smoking (mean \pm SD) } \\
\hline Everyday (n:28) & $1.6 \pm 1.3$ & $10.8 \pm 5.5$ & $p=0.001$ \\
\hline Weekly (n:13) & $1.0 \pm 0.8$ & $8.1 \pm 5.3$ & \\
\hline Monthly (n:18) & $1.4 \pm 1.4$ & $8.0 \pm 4.4$ & \\
\hline \multicolumn{4}{|l|}{ Occupation (mean \pm SD) } \\
\hline Student (n:37) & $1.4 \pm 1.1$ & $9.3 \pm 5.6$ & $p=0.001$ \\
\hline Unemployed+ Employed ( $\mathrm{n}: 22)$ & $1.4 \pm 1.5$ & $9.5 \pm 4.8$ & \\
\hline \multicolumn{4}{|l|}{ Has asthma diagnosis(mean \pm SD) } \\
\hline Yes $(n: 5)$ & $2.1 \pm 1.1$ & $8.1 \pm 4.7$ & $p=0.001$ \\
\hline No $(n: 54)$ & $1.4 \pm 1.2$ & $9.5 \pm 5.4$ & \\
\hline
\end{tabular}


There was no statistical association between the WPS frequency and mean eCO levels pre/post WPS ( $p=0.316$ and $p=0.125$, respectively). In addition, there were no statistical significances between mean pre/post WPS eCO levels and occupation, asthma diagnosis at the participant, parents cigarette smoking status or asthma diagnosis $(p>0.05)$.

Longer years of cigarette smoking had a significant positive correlation with age $(p=0.011, r=0.471)$.

There were significant positive correlations between post WPS eCO levels and daily cigarette consumption ( $p=0.044$, $r=0.383$ ), and pre and post WPS eCO levels, and years of WPS practice (respectively; $p=0.005, r=0.363 ; p=0.039, r=0.270$ ).

\section{DISCUSSION}

Waterpipe smoking is an increasing public health concern, which is spreading across the world currently, including the young. The researches addressing WPS are unsatisfactory. There is a need to distribute the information about waterpipes' health risks to all countries, by conducting more research on issues related to its use. ${ }^{[6,9]}$

According to our study, WPS in Ankara is prevalent among students and unemployed youth. This result correlate well with other studies done previously that WPS is becoming common in students. ${ }^{[4,10]}$ It is essential that young, in particular students be informed about health hazards of WPS.

It is reported that, socialization/partying and the influence of friends were found as common identified motivating factors with WPS. ${ }^{[4]}$ Similarly, the young in our study thought that WPS is a social event. Influence of friends was the most important factor to get addicted to WPS.

About an hour WPS causes the consumer being exposed to many harmful chemicals during this time. Although smoke in waterpipe contains a high density of $\mathrm{CO}$, nicotine, tar and heavy metals (arsenic, chrome, lead, nickel, cobalt, chrome, etc.), ${ }^{[11]}$ as a restriction factor of our study, we could only measure the increment in eCO levels. We measured pre and post WPS levels of eCO in the open air, in order to exclude the effects of in-door pollution, on CO levels of the smoker. We determined a significant increase in post WPS eCO levels. So, even though a person smokes waterpipe infrequently, a significant $\mathrm{CO}$ exposure occurs that he/she gets harmed by the aerosol of waterpipe.

Normal level of mean eCO in non-smokers was reported as $1.26 \mathrm{ppm}$, with a range from 0-6 ppm 12. In our study group, mean preWPS eCO level was $1.5 \pm 1.3 \mathrm{ppm}$ (min 0.1-max 5.6) and this level increased significantly after one hour WPS [9.4 $\pm 5.3 \mathrm{ppm}(\min 3-\max 25)](\mathrm{p}=0.001)$. In a study conducted by Akhter et al., baseline eCO levels $(27.7 \pm 4.9 \mathrm{ppm})$ and the eCO levels after WPS (57.9 \pm 27.4 ppm) were higher compared to our findings. ${ }^{[5]}$ The reason of this difference was our study group used WPS at open air and in august, however the study group in Akhter et al.s' were exposed to high amount of smoke due to in-door pollution, sitting in shisha bar causing significant increase in eCO levels. ${ }^{[5]}$ In other studies, which did not perform measurements in the open air, higher eCO levels were found after WPS compared to our study results. ${ }^{[13,14]}$

About half of our study group (47.5\%) was dual smokers (WPS and cigarette). It was reported that dual (WPS and cigarette) smoking rates are increasing amongst adolescents. Today, adolescents' WPS usage rates are more prevalent than cigarette smoking alone and dual use rates are on the rise among both genders. ${ }^{[15]}$ However, our study is the first to investigate preWPS and postWPS eCO levels of dual smoking population in the clean air.

Our study results showed significant baseline eCO levels in males and cigarette smokers even before initiation of smoking, therefore, these groups have a higher risk of $\mathrm{CO}$ exposure. Our study results also showed that post WPS eCO levels positively correlated with daily number of smoked cigarettes, and pre/ post WPS eCO levels positively correlated with waterpipe smoked years. This result might be referring that the increase in daily number of smoked cigarettes and many years WPS causes decreased lung capacity and CO elimination. However, the accuracy of this assessment cannot be proved with our available data.

In our study; among attendees five (8.5\%) had asthma diagnosis, and nine $(15.3 \%)$ had one of their parents with asthma. WPS significantly decreases pulmonary function parameters, including FEV1, FEV1/FVC ratio, and FEF, as well as the levels of FeNO. ${ }^{[16]}$ Exposure to waterpipe tobacco smoke can cause worsening asthma symptoms. Also maternal waterpipe smoking was significantly with allergic diseases, including asthma, allergic rhinitis and dermatitis. ${ }^{[17]}$

In our study group, $47.5 \%$ of the participants were WPS daily and $22 \%$ were smoking weekly or more frequently. In regular waterpipe smokers of a University's students in UK, 21.3\% were smoking daily with $52 \%$ smoked weekly or more frequently. [10] In regular WPS college students in Saudi Arabia, 14.9\% were reported as daily smokers. ${ }^{[18]}$ In our study group, daily waterpipe smokers are higher according to these studies. The reason for this result might be due to high rate of unemployed young (27.1\%).

Our study population comprised $79.7 \%$ males, and the mean age was $21.8 \pm 3.7$ years. In the US, waterpipe smokers were mostly males with ages between $15-25$ years. ${ }^{[19]}$ In Saudi Arabia similarly, $63.8 \%$ of students started WPS at ages of $16-$ 18 years, the male gender being dominant 16 . In Pakistan also, males were dominant users of waterpipe (53.6\%). ${ }^{[20]}$ Almost all studies show that WPS starts at adolescence and smokers are predominantly males. ${ }^{[4]}$ When developing WPS prevention programs to create awareness regarding its hazards, the target population should be males, with a focus on adolescents.

In a study conducted among university students in Jordan, female smokers mostly preferred waterpipe only to smoke in $53 \%$ and in association with cigarettes in $14 \%$. The place the female students had WPS was at home or somewhere else in $46.8 \%$ and at coffee shops in $53.2 \%{ }^{[19]}$ The study reported that 
WPS is increasing among women in the Eastern Mediterranean region because of more lax family and social attitudes related to it. ${ }^{[21]}$ In Turkey, it was shown that, although WPS was mostly used at cafes (called WPS café), $26.8 \%$ of the women and $9.7 \%$ of men smoked waterpipe at home. ${ }^{[22]}$ In this aspect, the low percentage of females in our study group might not reflect the real percentage of WPS female population, since a certain proportion might prefer private or home environment rather than public places to smoke, which might be difficult to study. In Turkey, more than 100,000 people die each year due to smoking, a number estimated to increase to 240,000 deaths by 2030 . Smoking was reported to be the most important risk factor for preventable deaths, in Turkey. Prevention of smoking would prevent 54,699 deaths, 52,905 in males and 1794 in females. However, there are no reports in Turkey attributed to health cost of WPS specifically. ${ }^{[22]}$

Our study identified that WPS in the open area of WPS cafes causes a considerable increase in hazardous chemical CO levels in exhaled breath. The risk groups for higher $\mathrm{CO}$ exposure were males, cigarette smokers and those with longer years of WPS practice. Environmental and policy controls, especially targeting high risk groups are needed to curb WPS.

As a conclusion WPS is continuing to spread among populations worldwide and perhaps represents the second global epidemic since that of cigarette; the prevalence being $6-39 \% \cdot{ }^{[4]}$ It is necessary to address issues related to social, health and dependence aspects of waterpipe use, with a focus on new ways of prevention.

Epidemiologic and toxicological researches are very important, as well as public health strategies for controlling the emerging epidemic of WPS should include implementation of laws to limit acquisition and use; and health education, targeting adolescents in particular. ${ }^{[2]}$ The present data might be a directive for public health policy makers to take preventive measures in order to restrain WPS in our country.

\section{ETHICAL DECLARATIONS}

Ethics Committee Approval: The ethics committee of Ministry of Health, Ankara Education and Research Hospital approved the study (Reference Number: 0058.286).

Informed Consent: All patients signed the free and informed consent form.

Referee Evaluation Process: Externally peer-reviewed.

Conflict of Interest Statement: The authors have no conflicts of interest to declare.

Financial Disclosure: The authors declared that this study has received no financial support.

Author Contributions: All of the authors declare that they have all participated in the design, execution, and analysis of the paper, and that they have approved the final version.

\section{REFERENCES}

1. World Health Organization Tobacco fact sheet. Available at: http://www. who.int/mediacentre/factsheets/fs339/en/. Accessed date: 12 December 2014.

2. Knishkowy B, Amitai Y. Water-pipe (narghile) smoking: an emerging health risk behavior. Pediatrics 2005;116(1):113-9.

3. Poyrazoğlu S, Sarli S, Gencer Z, Günay O. Waterpipe (narghile) smoking among medical and non-medical university students in Turkey. Ups J Med Sci 2010;115(3):210-6.

4. Aslam HM, Saleem S, German S, Qureshi WA. Harmful effects of shisha: literature review. Int Arch Med 2014;7:16.

5. Akhter S, Ali Warraich U, Rizvi N, Idrees N, Zaina F. Comparison of end tidal carbon monoxide (eCO) levels in shisha (water pipe) and cigarette smokers. Tob Induc Dis 2014;12(1):10.

6. Zyoud SH, Al-Jabi SW, Sweileh WM. Bibliometric analysis of scientific publications on waterpipe (narghile, shisha, hookah) tobacco smoking during the period 2003-2012. Tob Induc Dis 2014;12(1):7.

7. Alvur MT, Cinar N, Akduran F, Dede C. Fallacies about water pipe use in Turkish university students - what might be the consequences? Asian Pac J Cancer Prev 2014;15(5):1977-80

8. Turkish Statistical Institute Databases, Air quality statistics. Available at: http://www.turkstat.gov.tr/PreTablo.do?alt_id=1019. Accessed date: 5 March 2016.

9. Jawad M, Wilson A, Lee JT, Jawad S, Hamilton FL, Millett C. Prevalence and predictors of water pipe and cigarette smoking among secondary school students in London. Nicotine Tob Res 2013;15(12):2069-75.

10. Jackson D, Aveyard P. Waterpipe smoking in students: prevalence, risk factors, symptoms of addiction, and smoke intake. Evidence from one British university. BMC Public Health 2008;8:174.

11. Helen G, Benowitz NL, Dains KM, Havel C, Peng M, Jacob P. Nicotine and carcinogen exposure after water pipe smoking in hookah bars. Cancer Epidemiol Biomarkers Prev 2014;23(6):1055-66.

12. A Cunnington, $P$ Hormbrey. Breath analysis to detect recent exposure to carbon monoxide. Postgrad Med J 2002;78(918):233-7.

13. Singh S, Soumya M, Saini A, Mittal V, Singh UV, Singh V. Breath carbon monoxide levels in different forms of smoking. Indian J Chest Dis Allied Sci 2011;53(1):25-8.

14. Maziak W, Rastam S, Ibrahim I, Ward KD, Shihadeh A, Eissenberg T. CO exposure, puff topography, and subjective effects in waterpipe tobacco smokers. Nicotine Tob Res 2009;11(7):806-11.

15. Al-Sheyab N, Kheirallah KA, Mangnall LJ, Gallagher R. Agreement between exhaled breath carbon monoxide threshold levels and self-reported cigarette smoking in a sample of male adolescents in Jordan. Int J Environ Res Public Health 2015;12(1):841-54.

16. Qasim H, Alarabi AB, Alzoubi KH, Karim ZA, Alshbool FZ, Khasawneh FT. The effects of hookah/waterpipe smoking on general health and the cardiovascular system. Environ Health Prev Med 2019;24(1):58.

17. Waked M, Salameh P. Maternal waterpipe smoke exposure and the risk of asthma and allergic diseases in childhood: a post hoc analysis. Int J Occup Med Environ Health 2015;28(1):147-56.

18. Taha AZ, Sabra AA, Al-Mustafa ZZ, Al-Awami HR, Al-Khalaf MA, AlMomen MM. Water pipe (shisha) smoking among male students of medical colleges in the eastern region of Saudi Arabia. Ann Saudi Med 2010;30(3):222-6.

19. Brockman LN, Pumper MA, Christakis DA, Moreno MA. Hookah's new popularity among US college students: a pilot study of the characteristics of hookah smokers and their Facebook displays. BMJ Open 2012;2(6):e001709.

20. Jawaid A, Zafar AM, Rehman TU, et al. Knowledge, attitudes and practice of university students regarding waterpipe smoking in Pakistan. Int J Tuberc Lung Dis 2008;12(9):1077-84.

21. Dar-Odeh NS, Bakri FG, Al-Omiri MK, et al. Narghile (water pipe) smoking among university students in Jordan: prevalence, pattern and beliefs. Harm Reduct J 2010;7:10.

22. Global Adult Tobacco Survey, Turkey Report, Ministry of Health, Publ. No 803, 2010. Available at: http://www.who.int/tobacco/surveillance/en_tfi gats_turkey_2009.pdf. Accessed date: 4 March 2016. 